\title{
Interference of Drugs on Clinical Chemistry- Shall We Start Thinking?
}

\author{
Sharda Yadav" and Sanjaya KC \\ Central Clinical Laboratory, College of Medical Sciences, Bharatpur, Nepal \\ Email:shardaneps@gmail.com
}

\begin{abstract}
Clinical chemistry is emerging area in the field of clinical medicine which deals with the estimation of different analytes from body fluids. Different drugs interfere with the estimation of these analyte. The interference can be either physiological or analytical. Out of many analytes the most commonly estimated analyte are glucose, urea, creatinine, sodium and potassium. Small changes in these analytes also might give misleading information to the clinician. Though the clinicians will be aware of the major side effects of the drug, minor physiological effect might be overlooked also the analytical procedure and the effect of drug in different analytes. Hence, it is necessary for laboratory to inform clinicians regarding the possible effects of drugs on analytes.
\end{abstract}

Keyword: Drug interference, clinical chemistry, physiological interference, analytical interference

\section{Introduction}

Clinical chemistry is the branch in clinical medicine dealing with body fluids. The basic principle depends on the fact that a disease causes changes in biochemistry of the body. It may cause either increase in concentration, or decrease in concentration of certain biochemical parameters or even may cause a different substance to appear. Hence, clinical biochemistry deals with the changes in the composition of blood and other body fluids which are associated with the diagnosis of disease or monitoring the therapy.

Biochemical tests play an important part in clinical medicine for diagnosis of disease or to monitor therapy. So, it become challenging for a chemistry lab to provide accurate and reliable results. Many factors affect the accuracy of results in a clinical chemistry laboratory. Diurnal variation, circadian variation, seasonal variation, hydration state, eating habits and use of concurrent drugs affect the accuracy of test results. Drugs are one of the major interfering substances in biochemical tests.

Drugs interferes biochemical tests either

1. Physiologically (In vivo effects) and/or

2. Analytically (in vitro effects)

The In vivo effects are due to the intended (therapeutic) effects or side effects. The In vitro effects are caused due to

1. Alterations of chemical reactions (enhancement or inhibition)

2. Cause of turbidity in the reaction system

3. Interference with enzyme reactions

4. Cross-reaction with antibodies

\section{"Corresponding author}


Almost all the biochemical tests face the interference. Our experience in a tertiary care centre at Central Nepal shows that Random Blood Glucose, Urea, Creatinine and Electrolytes are routinely ordered by the physicians at every visit of the patient at the casualty department. At the referral centre, much effort is given to diagnose iatrogenic diseases and these biochemical parameters play a crucial role. There are evidences that the drug interference in the laboratory causes misinterpretations. With the advancement of analytical techniques more precise results are obtained in the clinical laboratory. But, physicians are generally uncertain how to interpret the small changes. Physicians are generally aware of the major effects of drugs administered, but may be unaware of the side effects or other biological effects. Only few are likely to know about the analytical techniques and the possibility of the administered drug effecting the concentration of the analyte.

To facilitate the physicians in the interpretation of the possible interference it is necessary to enlist the interferences of the drugs in specific tests.

\begin{tabular}{|c|c|c|c|c|}
\hline S.N. & Drug & Effect & Mode of Interference & Abnormality Reported \\
\hline \multicolumn{5}{|c|}{ Drug effecting Glucose } \\
\hline 1 & Ascorbic acid & Decrease & Analytical & $\begin{array}{l}\text { At concentration above } 150 \\
\mathrm{mg} / \mathrm{l} \text { it lowers glucose } \\
\text { concentration measured by } \\
\text { GOD method }\end{array}$ \\
\hline 2 & Cefuroxime & Decrease & Analytical & $\begin{array}{l}\text { False negative test may be } \\
\text { observed when ferric cyanide } \\
\text { methods are used to measure } \\
\text { glucose }\end{array}$ \\
\hline 3 & Metronidazole & Decrease & Analytical & $\begin{array}{l}\text { With hexokinase reaction } \\
\text { involving enzymatic coupling } \\
\text { with oxidation-reduction of } \\
\text { NAD. Interference may occur } \\
\text { due to the similar absorbance } \\
\text { peaks of NAD and } \\
\text { metronidazole }(322 \mathrm{~nm}) \text { at } \mathrm{PH} \\
7 \text {. }\end{array}$ \\
\hline 4 & Ciprofloxacin & Decrease & Physiological & $\begin{array}{l}\text { Concurrent administration of } \\
\text { ciprofloxacin with glyburide } \\
\text { has on rare occasions been } \\
\text { associated with severe } \\
\text { hypoglycemia. }\end{array}$ \\
\hline 5 & Propranol & Decreases & Physiological & $\begin{array}{l}\text { Has slightly effect like that of } \\
\text { prolong insulin. Rare cases } \\
\text { due to inhibition of } \\
\text { glycogenolysis } \\
\text { nondiabetics. }\end{array}$ \\
\hline 6 & Ramipril & Decrease & Physiological & $\begin{array}{l}\text { Slight but significant } \\
\text { reduction from mean baseline } \\
\text { of conc. of } 8.5 \mathrm{mmol} / \mathrm{L} \text { to } 8.0 \\
\text { mmol/L in } 21 \text { hypertensive } \\
\text { patients with noninsulin } \\
\text { dependent diabetes mellitus } \\
\text { treated with } 5 \mathrm{mg} / \text { day for } 12 \\
\text { weeks. Incidence of } 1.6 \%\end{array}$ \\
\hline
\end{tabular}




\begin{tabular}{|c|c|c|c|c|}
\hline & & & & $\begin{array}{l}\text { observed in French } \\
\text { pharmacovigilance database }\end{array}$ \\
\hline 7 & Sildenafil & Decrease & Physiological & $\begin{array}{lr}\text { Hypoglycemia } & \text { reaction } \\
\text { observed in some patients } \\
\text { when administered with } \\
\text { sildenafil. }\end{array}$ \\
\hline 8 & Furosemide & Increase & Physiological & $\begin{array}{l}\text { Hyperglycemia } \\
\text { alterations in glucose } \\
\text { tolerance may occur with } \\
\text { treatment. Diabetogenic like } \\
\text { action of drug affects glucose } \\
\text { tolerance tests. }\end{array}$ \\
\hline \multicolumn{5}{|c|}{ Drug effecting Urea } \\
\hline 1 & Atenolol & Increase & Physiological & $\begin{array}{l}\text { Increase in urea levels (mean } \\
\text { baseline } 9.0 \pm 3.0 \mathrm{mmol} / \mathrm{l} \text { to } \\
10.5 \pm 4.4 \mathrm{mmol} / \mathrm{l} \text { ) have been } \\
\text { seen in hypertensive patients } \\
\text { with proteinuria }\end{array}$ \\
\hline 2 & Enalapril & Increase & Physiological & $\begin{array}{l}\text { Increase noted }(8.2 \pm 3.1 \\
\mathrm{mmol} / \mathrm{l} \text { to } 11.4 \pm 3.4 \mathrm{mmol} / \mathrm{l}) \\
\text { in hypertensive patients with } \\
\text { proteinuria }\end{array}$ \\
\hline 3 & Albendazole & Increase & Physiological & $\begin{array}{l}\text { Acute renal failure observed } \\
\text { in patients receiving } \\
\text { albendazole leading to } \\
\text { elevated urea }\end{array}$ \\
\hline 4 & Methotrexate & Increase & Physiological & $\begin{array}{l}\text { May cause severe } \\
\text { nephropathy, azotemia. }\end{array}$ \\
\hline 5 & Prednisone & Decrease & Physiological & \begin{tabular}{ll}
\multicolumn{2}{l}{ Cases have been reported with } \\
low urea & concentration \\
following & Prednisolone \\
administration. & \\
\end{tabular} \\
\hline 6 & Streptomycin & Decrease & Analytical & $\begin{array}{l}\text { It inhibits Berthelot * } \\
\text { reaction. }\end{array}$ \\
\hline 7 & Chloramphenicol & Decrease & Analytical & It inhibits Berthelot* reaction. \\
\hline 8 & Guanethidine & Increase & Analytical & $\begin{array}{l}\text { It has chemical similarity to } \\
\text { urea. }\end{array}$ \\
\hline \multicolumn{5}{|c|}{ Drug effecting Creatinine } \\
\hline 1 & Cefixime & $\begin{array}{l}\text { Serum } \\
\text { Increase }\end{array}$ & Analytical & $\begin{array}{l}\text { It shows up to } 20 \% \text { increases } \\
\text { in Creatinine with Jaffe's } \\
\text { method }^{\#}\end{array}$ \\
\hline 2 & ACE inhibitors & $\begin{array}{l}\text { Serum } \\
\text { Increase }\end{array}$ & Physiological & $\begin{array}{l}\text { Serum Creatinine was } \\
\text { increased }(120 \pm 39 \mu \mathrm{mol} / \mathrm{L}) \\
\text { in patients using ACE } \\
\text { inihibitors compared to } \\
\text { controls }(103 \pm 25 \mu \mathrm{mol} / \mathrm{L})\end{array}$ \\
\hline
\end{tabular}




\begin{tabular}{|c|c|c|c|c|}
\hline 3. & Albendazole & $\begin{array}{l}\text { Serum } \\
\text { Increase }\end{array}$ & Physiological & $\begin{array}{l}\text { Acute renal failure observed } \\
\text { in patients }\end{array}$ \\
\hline 4. & Barbiturates & $\begin{array}{l}\text { Serum } \\
\text { Increase }\end{array}$ & Physiological & $\begin{array}{l}\text { Shock and renal failure in } \\
\text { intoxication }\end{array}$ \\
\hline 5. & Methyldopa & $\begin{array}{l}\text { Urine } \\
\text { Increase }\end{array}$ & Analytical & $\begin{array}{l}\text { Acts as reducing agent with } \\
\text { alkaline picrate }\end{array}$ \\
\hline 6. & Nitrofurans & $\begin{array}{l}\text { Urine } \\
\text { Increase }\end{array}$ & Analytical & $\begin{array}{l}\text { Reacts with reagents in Jaffe's } \\
\text { method }^{\#}\end{array}$ \\
\hline 7. & Corticosteroids & $\begin{array}{l}\text { Urine } \\
\text { Increase }\end{array}$ & Physiological & $\begin{array}{l}\text { Associated with negative } \\
\text { nitrogen balance }\end{array}$ \\
\hline 8. & Nandrolone & $\begin{array}{l}\text { Urine } \\
\text { Increase }\end{array}$ & Physiological & $\begin{array}{l}\text { Increase in Creatinine } \\
\text { concentration due to increase } \\
\text { in muscle mass }\end{array}$ \\
\hline 9. & Prednisone & $\begin{array}{l}\text { Serum } \\
\text { Increase }\end{array}$ & Physiological & $\begin{array}{l}\text { Significant decrease (from } \\
717 \pm 103 \mu \mathrm{mol} / 1 \text { to } 262 \pm 31 \\
\mu \mathrm{mol} / \mathrm{l} \text { ) has been noted in } \\
\text { patients with HIV associated } \\
\text { nephropathy }\end{array}$ \\
\hline \multicolumn{5}{|c|}{ Drug effecting Sodium } \\
\hline 1 & Lactulose & Increase & Physiological & $\begin{array}{l}\text { Hypernatremia has been } \\
\text { reported infrequently during } \\
\text { lactulose treatment of the } \\
\text { portal-systemic } \\
\text { encephalopathy. Due to its } \\
\text { osmotic cathartic effects, the } \\
\text { drug may cause fecal water } \\
\text { loss in excess of sodium } \\
\text { resulting in contraction of } \\
\text { ECF volume and } \\
\text { hypernatremia. Reducing dose } \\
\text { to produce not more than } 2 \text { to } \\
3 \text { soft stools dialy in order } \\
\text { toavoid severe water loss is } \\
\text { suggested. }\end{array}$ \\
\hline 2 & Lithium & Increase & Physiological & $\begin{array}{l}\text { Diabetes Insipidus like } \\
\text { syndrome with lithium had } \\
\text { been reported after } 2 \text { weeks of } \\
\text { therapy and is usually } \\
\text { reversible on discontinuation } \\
\text { of the drug. While affected, } \\
\text { however, many patients are } \\
\text { unresponsive to exogenous } \\
\text { Antidiuretic hormone. }\end{array}$ \\
\hline 3 & Demeclocycline & Increase & Physiological & $\begin{array}{l}\text { Demeclocycline can also } \\
\text { cause Diabetes Insipidus and } \\
\text { has been used in the } \\
\text { management of patients with } \\
\text { the Syndrome of } \\
\text { Inappropriate Antidiuretic }\end{array}$ \\
\hline
\end{tabular}




\begin{tabular}{|c|c|c|c|c|}
\hline & & & & Hormone (SIADH). \\
\hline 4 & Phenytoin & Increase & Physiological & $\begin{array}{l}\text { Phenytoin inhibits ADH } \\
\text { secretion at the level of the } \\
\text { central nervous system and is } \\
\text { known to cause } \\
\text { hypernatremia. }\end{array}$ \\
\hline 5 & Amiloride & Decrease & Physiological & $\begin{array}{l}\text { Amiloride combined with } \\
\text { hydrochlorothiazide has been } \\
\text { implicated. Amiloride may be } \\
\text { the offending agent because } \\
\text { patients have tolerated } \\
\text { hydrochlorothiazide with a } \\
\text { potassium supplement. }\end{array}$ \\
\hline 6 & Captopril & Decrease & Physiological & $\begin{array}{l}\text { In } 5 \text { men with } \mathrm{CHF} \text {, serum } \\
\text { sodium fell by } 7 \mathrm{mmol} / \mathrm{L} \text { on } \\
\text { the } 3^{\text {rd }} \text { to } 4^{\text {th }} \text { days. }\end{array}$ \\
\hline 7 & Diclofenac & Decrease & Physiological & $\begin{array}{l}\text { It enhances the actions of } \\
\text { ADH due to prostaglandin } \\
\text { inhibition. Water intoxication } \\
\text { and hyponatremia only occur } \\
\text { with NSAIDs in clinical } \\
\text { practice in patients in a state } \\
\text { of endogenous or exogenous } \\
\text { active antidiuretic hormone } \\
\text { secretion, such as in elderly or } \\
\text { neonatal patients, chronic } \\
\text { renal failure, low salt diet, } \\
\text { excessive oral water intake or } \\
\text { heart failure, or concurrent } \\
\text { analgesic use. }\end{array}$ \\
\hline$\varepsilon$ & Glimeperide & Decrease & Physiological & $\begin{array}{l}\text { Although specific cases are } \\
\text { lacking, the drug is capable of } \\
\text { inducing SIADH, similar to } \\
\text { other sulfonylureas. }\end{array}$ \\
\hline $\mathrm{c}$ & Oxytocin & Decrease & Physiological & $\begin{array}{l}\text { Continuous } \\
\text { intravenous } \\
\text { infusion of oxytocin in } \\
\text { electrolyte-free solutions has } \\
\text { resulted in water intoxication. } \\
\text { This usually occurs when } \\
\text { administration rate for } \\
\text { oxytocin is greater than } 45 \\
\text { milliunits/minute. }\end{array}$ \\
\hline \multicolumn{5}{|c|}{ Drug effecting Potassium } \\
\hline 1 & Amphotericin B & Decrease & Physiological & $\begin{array}{l}\text { In clinical trials, of the } 556 \\
\text { patients treated with } \\
\text { Amphotericin B, } 5 \% \text { had } \\
\text { hypokalemia. This is } \\
\text { potentially caused by the } \\
\text { concurrent administration of }\end{array}$ \\
\hline
\end{tabular}




\begin{tabular}{|c|c|c|c|c|}
\hline & & & & $\begin{array}{ll}\text { corticosteroids } & \text { and } \\
\text { corticotrophin. } & \\
\end{array}$ \\
\hline 2 & Glucose & Decrease & Physiological & $\begin{array}{l}\text { Insulin, together with glucose } \\
\text { to prevent hypoglycemia is } \\
\text { given to stimulate cellular } \\
\text { uptake of potassium in } \\
\text { emergency treatment of } \\
\text { moderate to severe } \\
\text { hyperkalemia. }\end{array}$ \\
\hline 3 & Enalapril & Increase & Physiological & $\begin{array}{l}\text { May cause hyperkalemia in } \\
\text { approximately } 1 \% \text { patients } \\
\text { treated with Enalapril. In } 427 \\
\text { patients with essential } \\
\text { hypertension, treatment for } 6 \\
\text { months caused significant } \\
\text { increase in plasma potassium } \\
\text { from a baseline of } 4.2 \pm 0.4 \\
\text { mmol/L to } 4.3 \mathrm{mmol} / \mathrm{L} \text {. }\end{array}$ \\
\hline 4 & Cyclosporin & Increase & Physiological & $\begin{array}{l}\text { Significant hyperkalemia } \\
\text { sometimes associated with } \\
\text { hyperchloremic metabolic } \\
\text { acidosis and hyperurecemia } \\
\text { has been seen in individual } \\
\text { patients receiving } \\
\text { cyclosporine. Of } 266 \text { treated } \\
\text { patients, hyperkalemia was } \\
\text { observed in } 26(10 \%) \text { one } \\
\text { year after liver transplant with } \\
\text { cyclosporin used as } \\
\text { immunosuppressant. }\end{array}$ \\
\hline 5 & Amiloride & Increase & Physiological & $\begin{array}{l}\text { It can cause hyperkalemia, } \\
\text { particularly in elderly } \\
\text { patients, and in patients with } \\
\text { impaired renal function. }\end{array}$ \\
\hline 6 & Digoxin & Increase & Physiological & $\begin{array}{l}\text { In } 10 \text { healthy individuals who } \\
\text { had received digoxin for } 10 \\
\text { days, serum potassium } \\
\text { concentration increases from } \\
\text { mean baseline of } 4.2 \pm 0.3 \\
\text { mmol/L to } 4.4 \pm 0.3 \mathrm{mmol} / \mathrm{L} \\
\text { after } 2 \text { hour supine rest. }\end{array}$ \\
\hline 7 & Succinylcholine & Increase & Physiological & $\begin{array}{l}\text { Increased chemosensitivity of } \\
\text { muscle membrane and } \\
\text { development of receptor site } \\
\text { in extrajunctional areas causes } \\
\text { transient hyperkalemia in } \\
\text { patients undergoing general } \\
\text { anesthesia. }\end{array}$ \\
\hline
\end{tabular}


* Berthelot reaction is one of the common methods of urea estimation

\# Jaffe's method is one of the common methods of Creatinine estimation in clinical chemistry laboratory using alkaline picrate as one of the reagents

\section{Conclusion}

Different drugs at different doses interfere with the estimation of different analytes in clinical laboratory. Sometimes the interference is physiological or sometime merely analytical. Most of the times this factor is overlooked but this might be an important factor for deviated laboratory values. In a situation, where a small change of the value in the analytes changes the diagnosis and overall treatment process it is necessary for not only the laboratory but also for the treating clinician.

\section{Acknowledgements}

The authors acknowledge Dr. P Subish and Dr. Kadir Alam for permission to use the facilities at the Drug Information Centre at, Manipal Teaching Hospital.

\section{References}

1. Young DS, Effect of drugs in clinical laboratory tests, Advancing clinical laboratory science. Vol I Worldwide Publishing Company, Washington DC, 1999.

2. Young DS, Effect of drugs in clinical laboratory tests, Advancing clinical laboratory science. Vol II Worldwide Publishing Company, Washington DC, 1999.

3. Indian Drug Review. Nov-Dec 2003, IX.

4. Satoskar RS, Pharmacology and Pharmacotherapeutics, Popular Prakashan, Mumbai. Revised Sixteenth Edition, 1999.

5. Wynne HA, Edwards C, Laboratory Data in Walker R, Edwards C, In Clinical Pharmacy and therapeutics, Churchill Livingstone edited by: Walker R \& Edwards C, $3^{\text {rd }}$ edition, 2003, 51-53.

6. Beers MH and Berkow R, The Merck Manual, Merck Research Laboratories, The Merck Manual, $17^{\text {th }}$ Edition 1999; 134-41.

7. Kazmierczak SC, Catrou PG, Am. J. Clin Pathol 2000, 113, 9.

8. Kailajarvi M, Takala T, Gronroos P, Tryding N, Viikari J, Irjala K, Clin Chem, 2000, 46(9), 1395.

9. Saibaba KSS, Bhaskar MV, Srinivasa Rao PVLN, Ramana GV, Dakshinamurty KV, Ind. J. of Clin. Biochem., 1998, 13(2), 55.

10. Young DS, Thomas DW, Friedman RB, J. Clin. Path., 1972, 25, 984. 